\title{
PENGEMBANGAN MASYARAKAT MUSLIM MINORITAS PASCA BENCANA ERUPSI GUNUNG SINABUNG DI DESA SIOSAR KAB. KARO
}

\author{
Farhan Indra \\ Kementerian Agama Wilayah Sumatera Utara \\ buyafarhanindra@gmail.com
}

\begin{abstract}
The Muslim community in Karo Regency is included as a minority group. The prolonged eruption of Mount Sinabung forced many people to be relocated from their original places to new locations. Relocation not only uproots what already exists economically but also socioculturally and religiously. Therefore, the development aspect of the minority Muslim community is important to be seen as a study to explain how the development occurred. Siosar Village is a new relocation site, where the Muslim community as a minority is the focus of this research with a qualitative approach, the main finding of this research is, the development of minority Muslim communities is mostly carried out by various religious institutions from educational institutions, religious organizations to volunteers. The impetus for development starts from symbolic aspects such as places of worship with all the necessary equipment, other developments are strengthening Islamic teachings, especially in terms of faith and worship. The motive for this development was carried out because of the concern aspect where Muslims as a minority could be eroded and in order to maintain the dignity of Islam as a religion that has a strong ukhuwah Islamiyah.
\end{abstract}

Keywords: minority Islam, community development, Siosar Village

\begin{abstract}
Abstrak
Masyarakat muslim di Kabupaten Karo termasuk sebagai kelompok minoritas. Bencana erupsi gunung Sinabung yang berkepanjangan memaksa banyak masyarakat yang harus direlokasi dari tempat semula ke lokasi yang baru. Relokasi tidak hanya mencerabut apa yang sudah ada secara ekonomi melainkan juga sosial budaya dan agama. Oleh karena itu aspek pengembangan masyarakat muslim minoritas menjadi penting untuk dilihat sebagai kajian untuk menjelaskan bagaimana perkembangan yang terjadi. Desa Siosar adalah tempat relokasi baru, di tempat tersebut masyarakat muslim sebagai minoritas menjadi fokus penelitian ini dengan pendekatan kualitatif, temuan utama penelitian ini adalah, pengembangan masyarakat muslim minoritas banyak dilakukan oleh berbagai lembaga keagamaan mulai institusi pendidikan, organisasi keagamaan sampai relawan. Dorongan pengembangan mulai dari aspek simbolik seperti tempat ibadah dengan segala peralatan yang dibutuhkan, pengembangan lainnya yaitu penguatan ajaran Islam terutama dalam hal akidah dan ibadah. Motif dari pengembangan ini dilakukan karena aspek kekhawatiran di mana orang-orang muslim sebagai minoritas dapat tergerus dan demi menjaga marwah Islam sebagai agama yang memiliki ukhuwah islamiyah yang kuat.
\end{abstract}

Kata kunci: Islam minoritas, pengembangan masyarakat, Desa Siosar 


\section{PENDAHULUAN}

Gunung Sinabung (bahasa Karo: Deleng Sinabung) adalah gunung api di Dataran Tinggi Karo, Kabupaten Karo, Sumatera Utara, Indonesia dengan ketinggian 2460 M. Gunung ini tidak pernah tercatat meletus sejak tahun 1600, tetapi mendadak aktif kembali dan meletus pertama kali pada Agustus tahun 2010. Setelah mereda beberapa waktu letusan kembali terjadi tahun 2013. Sejak terjadi letusan sangat besar di tahun 2013, yaitu pada Minggu 16 September 2013, gunung Sinabung terus aktif hingga kini sampai tahun 2018. Artinya secara rutin mengeluarkan luncuran lava, lidah api, dan gempa, walaupun intensitasnya turun naik.

Aktivitas Sinabung sempat menurun sehingga pada 10 Februari 2014, pengungsi dari 17 desa yang berasal dari desa-desa di luar radius $5 \mathrm{~km}$ diperbolehkan untuk pulang ke rumah mereka. Namun, berdasarkan hasil pemantauan Badan Vulkanologi dan Mitigasi Bencana Indonesia, status Gunung Sinabung sampai dengan tanggal 26 Maret 2014 masih pada level IV (Awas) atau level paling tinggi di mana aktifitas gempa dan erupsi frekuensinya tetap tinggi. Dan ternyata, ancaman Sinabung terus berlangsung sampai setelah 4 tahun kemudian, yaitu ketika penelitian ini dilakukan pada Maret 2018. Baru-baru ini Gunung Sinabung kembali menunjukkan aktifitas letusannya yang berbahaya, terakhir mencapai kolom letusan setinggi 5000 meter pada 19 Pebruari 2018.

Letusan yang terus menerus terjadi mengakibatkan banyak wilayah disekitaran lereng gunung Sinabung rusak parah, khususnya beberapa desa tidak bisa lagi ditempati, selain adanya ancaman letusan yang kapan saja bisa datang dan mengancam banyak korban, lokasi rumah yang hancur, lahan-lahan yang sudah tidak memungkinkan untuk diolah kembali.

Situasi demikian menjadikan pemerintah mengambil kebijakan merelokasi beberapa desa ke wilayah yang dianggap lebih aman, yaitu wilayah Siosar. SIOSAR berada di Kecamatan Merek. Dulu adalah kawasan hutan dan kemudian dijadikan lokasi resmi untuk relokasi masyarakat terdampak letusan Gunung Sinabung. Lahan yang letaknya sangat terpencil ini sudah mendapat izin secara resmi dan merupakan satu-satunya alternatif lokasi perancangan untuk permukiman relokasi masyarakat Gunung Sinabung. Menurut pak Sulaiman makna kata SIOSAR adalah di belakang. Artinya, dulu wilayah ini tidak mendapat perhatian, terasing, dan letaknya di paling ujung yang tidak ada pemukiman setelahnya. ${ }^{1}$

\footnotetext{
${ }^{1}$ Wawancara, Bapak Sulaiman, warga muslim Siosar. 


\section{JURNAL PEMBERDAYAAN MASYARAKAT 201 \\ Volume 9 No. 2 Tahun 2021 ISSN: 2355-8679}

Siosar dulunya merupakan area Hutan yang Luas. Semenjak Gunung Sinabung mengalami Erupsi lebih dari 2 tahun lamanya, akhirnya Areal hutan Siosar dibuka untuk pembangunan rumah-rumah para pengungsi Sinabung. Nantinya menjadi rumah tetap yang bisa ditinggali para pengungsi Sinabung tersebut. Sampai sekarang pembangunan rumahrumah masih berlanjut, sampai para pengungsi bisa mendapatkan rumah masing-masing di Siosar ini.

Relokasi ini berada di kawasan hutan produksi di Siosar, Kecamatan Merek, Kabupaten Karo, Provinsi Sumatera Utara, sekitar 17 km dari kota Kabanjahe, ibu kota Kabupaten Karo. Penggunaan lahan dan akses jalan pada kawasan hutan produksi tetap Siosar, dan hutan lindung sekitar 458,8 hektare. TNI adalah pihak yang oleh masyarakat dianggap berperan besar dalam pembukaan kawasan pemukiman ini. Dilihat dari topografinya, Siosar adalah kawasan perbukitan yang dengan posisinya memiliki potensi sebagai kawasan wisata. Beberapa puncak gunung yang memiliki pemandangan yang indah dapat dinikmati dari kawasan ini.

Relokasi ini menimbulkan situasi baru khususnya bagi umat Islam di sana, selain karena dalam struktur sosial adalah kelompok minoritas da nada yang bukan beretnis Karo maka situasi ini menjadi perhatian banyak kalangan khususnya yang berada di luar Siosar. Berbagai lembaga memberikan perhatian khusus atas hal ini, mulai dari lembaga keagamaan, organisasi keagamaan, lembaga NGO berbasis agama dan sejenisnya. Beberapa hal yang dilakukan adalah fokus pada pengembangan masyarakat muslim di sana, meliputi hal-hal yang berhubungan dengan sarana dan prasarana tapi juga terkait dengan kebutuhan pengajaran. Penelitian ini memotret situasi tentang pengembangan yang dilakukan khususnya dari berbagai pihak yang memiliki kepedulian.

Secara umum pengembangan masyarakat (community development) dalam bahasa Arab disebut dengan tathwirul mujtamá il-islamiy adalah kegiatan pengembangan masyarakat yang dilakukan secara sistematis, terencana,dan diarahkan untuk memperbesar akses masyarakat guna mencapai kondisi sosial, ekonomi, dan kualitas kehidupan yang lebih baik apabila dibandingkan dengan kegiatan pembangunan sebelumnya (Budimata \& Rutio, 2008). Ibnu Khaldun mengatakan bahwa secara etimologi pengembangan berarti membina dan meningkatkan kualitas. Masyarakat Islam berarti kumpulan manusia yang beragama Islam, yang meneliti hubungan dan keterkaitan ideologis yang satu dengan yang lainnya. Dalam pemikiran sosiologis, Ibnu Khaldun menjelaskan bahwa manusia itu secara individu diberikan kelebihan, namun secara kodrati manusia memiliki kekurangan. Sehingga 


\section{JURNAL PEMBERDAYAAN MASYARAKAT 202 \\ Volume 9 No. 2 Tahun 2021 ISSN: 2355-8679}

kelebihan itu perlu dibina agar dapat mengembangkan potensi pribadi untuk dapat membangun (Fu'ad dalam Ismail, 2006).

Pola pemberdayaan masyarakat bukan merupakan kegiatan yang sifatnya top-down intervention yang tidak menjunjung tinggi aspirasi dan potensi masyarakat untuk melakukan kegiatan swadaya, karena yang paling dibutuhkan masyarakat lapisan bawah terutama yang tinggal di desa adalah pola pemberdayaan yang sifatnya bottom-up intervention yang menghargai dan mengakui bahwa masyarakat lapisan bawah memiliki potensi untuk memenuhi kebutuhannya, memecahkan permasalahannya, serta mampu melakukan usahausaha produktif dengan prinsip swadaya dan kebersamaan. Dakwah adalah upaya mengajak masyarakat menuju cara hidup islami dalam segala aspek kehidupan, baik aspek kerohanian, maupun aspek sosial ekonomi, politik, budaya dan hukum yang ada di masyarakat. Term dakwah secara etimologi adalah bentuk mashdar dari kata kerja da'a yad'u- da'watan atau du'aan yang berarti menyeru, mengajak, memanggil, mengadu, berdo'a, memohon, menyuruh dan meminta (Sihotang, 2012). Dari seluruh makna dakwah tersebut terdapat makna komunikasi antara da'i dengan mad'u. Komunikasi tersebut dapat berbentuk ceramah, bimbingan dan juga pengembangan masyarakat. Dalam al-Quran term dakwah dalam berbagai bentuknya ditemukan sebanyak 299 kali (Suhu dkk, 2005).

Pada hakikatnya semua pembangunan dilaksanakan untuk meningkatkan kesejahteraan masyarakat baik jasmani maupun rohani. Untuk itu pembangunan terhadap masyarakat desa dan kota dipusatkan pada mereka (people centered development) melalui suatu gerakan yang dinamakan pengembangan masyarakat (community development) sebagaimana rumusan konsep Brokensha dan Hodge: Community development is a movement designed to promote better living for the whole community with the active participation and on the initiative of the community (Pengembangan masyarakat adalah suatu gerakan yang dirancang guna meningkatkan taraf hidup keseluruhan masyarakat melalui partisipasi aktif dan inisiatif dari masyarakat).

\section{METODE PENELITIAN}

Jenis penelitian ini adalah penelitian deskriptif dengan pendekatan kualitatif. Metode pengumpulan data dilakukan dengan cara wawancara, observasi dan dokumentasi. Observasi dilakukan dengan mengamati dan mencatat segala fenomena yang berhubungan dengan peristiwa letusan Sinabung, relokasi penduduk, dan kondisi serta struktur sosial keagamaan Masyarakat Muslim Relokasi Sinabung. Dokumentasi dilakukan dengan mengumpulkan dan 
menginterpretasikan segala dokumen misalnya data penduduk dan laporan serta dokumen lain yang berhubungan dengan objek penelitian.

\section{HASIL DAN PEMBAHASAN}

Kabupaten Karo terletak diantara 2०50” - 3¹9” Lintang Utara serta pada $97^{\circ} 55$ 98 38* Bujur Timur merupakan bagian dari wilayah pada posisi silang di kawasan Palung Pasifik Barat dengan luas wilayah 2.127,25 $\mathrm{Km}^{2}$ atau merupakan 2,97\% dari luas Propinsi Sumatera Utara. Berbatas sebelah Utara dengan Kabupaten Langkat dan Kabupaten Deli Serdang, Sebelah Selatan dengan Kabupaten Dairi dan Samosir, Sebelah Barat dengan Propinsi Nangroe Aceh Darussalam, Sebelah Timur dengan Kabupaten Deli Serdang dan Simalungun. Hampir $50 \%$ luas wilayah Karo berisikan tanaman mata pencaharian masyarakat, tanaman kebutuhan pangan, hutan produksi, tanaman tahunan, dan sejenisnya. Dapat dikatakan bahwa hampir $90 \%$ kebutuhan sayuran dan tanaman buah penduduk Kota Medan berasal dari Kabupaten Karo.

Kabupaten Karo secara Topografis terletak pada jajaran bukit barisan dan sebagian besar merupakan dataran tinggi berada 120-1420 di atas permukaan laut. Dua gunung berapi aktif terletak di wilayah ini. Kabupaten Karo merupakan Daerah Hulu Sungai (DHS) dan Daerah Aliran Sungai (DAS) Wampu/Ular, sub Daerah Aliran Sungai Laubiang, yang kesemuanya bermuara ke Selat Malaka. Pada umumnya sub DAS ini dimanfaatkan untuk mengairi areal persawahan sebagai upaya peningkatan produksi pertanian. Dengan pusat pemerintahan berada di Kabanjahe, kabupaten Karo secara administratif terdiri dari 17 Kecamatan dan 262'Desa/Kelurahan (252 desa dan 10 kelurahan), dengan jumlah penduduk 396.598 Jiwa (BPS, 2009)

Suku Karo merupakan sebuah suku yang mendiami wilayah Sumatera Utara dan sebagian Aceh. Suku ini merupakan salah satu suku terbesar dalam Sumatera Utara. Nama suku ini dijadikan salah satu nama Kabupaten di salah satu wilayah yang mereka diami (dataran tinggi Karo) yaitu Tanah Karo yang terletak di kabupaten karo. Suku ini memiliki bahasa sendiri yang disebut bahasa Karo atau Cakap Karo. Pakaian adat suku Karo didominasi dengan warna merah serta hitam dan penuh dengan perhiasan emas. Suku Karo adalah merupakan suku asli pertama Kota Medan karena Kota Medan didirikan oleh seorang putra Karo yang bernama Guru Patimpus Sembiring Pelawi. Suku Karo pada mulanya tinggal di dataran tinggi Karo yakni Brastagi dan Kabanjahe. 
Suku Karo memiliki sistem kemasyarakatan atau adat yang dikenal dengan nama merga silima, tutur siwaluh, dan rakut sitelu. Merga disebut untuk laki-laki, sedangkan untuk perempuan yang disebut beru. Merga atau beru ini disandang di belakang nama seseorang. Merga dalam masyarakat Karo terdiri dari lima kelompok, yang disebut dengan merga silima. Kelima merga tersebut adalah:

1. Karo-karo: Purba, Barus, Bukit, Gurusinga, Kaban, Kacaribu, Surbakti, Sinulingga, Sitepu, Sinuraya, Sinuhaji, Ketaren, kemit, jung, sinukaban, sinubulan, samura, sekali. (berjumlah 18)

2. Tarigan: bondong, gana-gana, gersang, gerneng, jampang, purba, pekan, sibero, tua, tegur, tambak, tambun, silangit, tendang. (berjumlah 14)

3. Ginting: anjartambun, babo, beras, cabap, gurupatih, garamata, jandibata, jawak, manik, munte, pase, seragih, suka, sugihen, sinusinga, tumangger, taling kuta. (berjumlah 17)

4. Sembiring: Sembiring si banci man biang (sembiring yang boleh makan anjing): Keloko, Sinulaki, Kembaren, Sinupayung (Jumlah = 4); Sembiring simantangken biang (sembiring yang tidak boleh makan Anjing): Brahmana, Depari, Meliala, Pelawi, busuk, colia, muham, maha, bunuaji, gurukinayan, pandia, keling, pandebayang, sinukapur, tekang. (berjumlah 15)

5. Perangin-angin: Bangun, Keliat, Kacinambun, Namohaji, Mano, Benjerang, Uwir, Pinem, Pancawan, Penggarun, Ulun Jandi, Laksa, Perbesi, Sukatendel, Singarimbun, Sinurat, Sebayang, Tanjung. (berjumlah 18).

Kelima merga ini masih mempunyai submerga masing-masing. Setiap orang Karo mempunyai salah satu dari merga tersebut. Merga diperoleh secara turun termurun dari ayah. Merga ayah juga merga anak. Orang yang mempunyai merga atau beru yang sama, dianggap bersaudara dalam arti mempunyai nenek moyang yang sama. Kalau laki-laki bermarga sama, maka mereka disebut (b)ersenina, demikian juga antara perempuan dengan perempuan yang mempunyai beru sama, maka mereka disebut juga (b)ersenina. Namun antara seorang lakilaki dengan perempuan yang bermerga sama, mereka disebut erturang, sebingga dilarang melakukan perkawinan, kecuali pada merga Sembiring dan Perangin-angin yang diperbolehkan melakukan prosesi pernikahan di antara mereka.

Berikut ini merupakan data setiap pemeluk agama berdasarkan jumlah pemeluk agama di Kabupaten Karo. 
\begin{tabular}{r|l} 
JURNAL PEMBERDAYAAN MASYARAKAT & 205 \\
Volume 9 No. 2 Tahun 2021 & ISSN: 2355-8679
\end{tabular}

Table 1. Data Penduduk Kabupaten Karo Berdasarkan Agama

\begin{tabular}{|c|l|c|}
\hline No & \multicolumn{1}{|c|}{ Agama } & Jumlah \\
\hline 1 & Protestan & $57,59 \%$ \\
\hline 2 & Islam & $24,15 \%$ \\
\hline 3 & Katolik & $17,46 \%$ \\
\hline 4 & Hindu & $0,02 \%$ \\
\hline 5 & Budha & $0,56 \%$ \\
\hline 6 & Konghucu & $0,23 \%$ \\
\hline
\end{tabular}

Penduduk di Kabupaten Karo umumnya adalah suku Karo dan mayoritas menganut agama Kristen. Data BPS Kabupaten Karo 2020, yang beragama Kristen sebanyak 75,04\% (Kristen Protestan 57,59\% dan Katolik 17,46\%) dari 415.878 jiwa penduduk pada tahun 2019. Selain itu agama Islam juga banyak dianut penduduk Kabupaten Karo, yakni mencapai 24.15\% dan agama Buddha 0,56\%, Konghucu 0,23\% dan Hindu 0,02\%.

Penduduk Daerah tingkat II Karo adalah masyarakat suku bangsa Karo dan kemudian lambat laun dengan sendirinya banyak ditambah pendatang lain seperti suku Tapanuli, Jawa, Simalungun, Cina, dan lainnya yang datang dari penjuru nusantara walau dalam jumlah yang terbatas. Mayoritas penduduk Kabupaten Karo memeluk agama Kristen Protestan.

Mata Pencaharian penduduk Kabupaten Karo menurut Sensus Penduduk tahun 1994 dijelaskan dalam keterangan berikut (BPS, 2010):

1. Pertanian 79,93

2. Pedagang 11,49

3. Pegawai Negeri 9,17

4. Transportasi 1,13

5. Konstruksi 1,12

6. Industri 0,64

7. Pertambangan 0,32

8. Keuangan 0,09

9. Perusahaan Listrik, Gas, Air Mineral 0,87

10. Lain-lain $0,37$.

\section{Pengembangan Masyarakat Minoritas Relokasi Erupsi Gunung Sinabung}

Masyarakat muslim minoritas di Tanah Karo dan khususnya di wilayah relokasi merupakan satu sub kultur dalam system social masyarakat Karo (Azra, 2008). Secara 
komposisi mereka tergolong sebagai etnis pendatang dan juga etnis karo itu sendiri. System budaya Karo tidak membedakan agama apa yang dianut oleh masyarakatnya melainkan perpegang teguh pada system nilai budaya yang sayangnya tidak selalu sejalan dengan ajaran Islam dalam beberapa hal.

Dalam kultur demografi yang sudah lama dibangun saat masyarakat yang sekarang mendiami wilayah Siosar, masyarakat muslim sudah memiliki kemampuan untuk survey dalam hal pengembangan masyarakat, khususnya terkait urusan internal umat, seperti soal akidah, ibadah. Hal ini seperti dituturkan oleh Bapak Ginting

"kalau ditempat tinggal kami dulu, kami sudah punya tempat ngaji anak-anak, ada masjid ada, ada pengajian yang dilaksanakan oleh ustadz penyuluh, meskipun tidak begitu rutin, tapi urusan agama masih ada kekompakan diantara kami yang muslim. Tapi begitu pindah ke Siosar, kami sibuk ngurusi urusan tempat tinggal, urusan makan, urusan sekolah anak-anak sampai kami tidak terpikir urusan agama, anak-anak sudah tidak lagi belajar agama di sini, banyak yang berubah dari tempat tinggal kami dulu, makanya kami sangat senang kalau banyak pihak dari luar seperti Medan, ormas, ulama, ustadz memiliki kepedulian sama kami yang di sini."2

Persoalan pengembangan masyarakat minoritas memang menjadi konsen yang sangat serius bagi banyak kalangan umat Islam di perkotaan, banyak lembaga yang memberikan perhatian. Majelis Ulama Indonesia misalnya memberikan perhatian melalui subsidi tunjangan honor bagi dai atau penyuluh agama yang ditugaskan di wilayah minoritas. Lembaga dakwah menyelenggarakan berbagai pengabdian dakwah, pengkaderan, pengajian dan syiar-syiar keagamaan secara simultan.

Terkait dengan masyarakat Siosar berbagai unsur terlibat dalam pengembangan masyarakat muslim di sana, mulai dari pendirian tempat ibadah seperti mushola sebagai ruang aktivitas keagamaan sekaligus sosial kemasyarakatan, meskipun ada Jambur ${ }^{3}$ sebagai

${ }^{2}$ Wawancara, Bapak Ginting, Warga Siosar beragama Islam.

${ }^{3}$ Jambur adalah bangunan luas yang dipergunakan sebagai ruang serba guna khas masyarakat Suku Karo dari Sumatra Utara. Pada umumnya bangunan jambur digunakan sebagai tempat pelaksanaan pesta-pesta adat Karo, baik pesta adat pernikahan maupun pesta adat kematian. Keberadaan bangunan jambur secara umum tidak berdinding dan berpanggung dan pada setiap daerah Karo keberadaan bangunan ini akan mudah ditemukan, baik di kota Medan, Kabanjahe, Berastagi, dan juga diberbagai desa-desa yang ada di Tanah Karo. Jambur dilengkapi dengan dapur umum yang cukup besar dengan peralatan memasak untuk ukuran acara besar, serta dilengkapi dengan toilet. Ketika ada pesta masyarakat atau tuan rumah tidak perlu repot-repot menyewa tenda atau tratak dengan biaya yang cukup besar. 


\section{JURNAL PEMBERDAYAAN MASYARAKAT 207 \\ Volume 9 No. 2 Tahun 2021 ISSN: 2355-8679}

tempat aktivitas sosial masyarakat Karo, tapi kebutuhan tempat ibadah adalah hal yang berbeda.

Ibu Melania Sembiring mengutarakan bahwa orang Karo apapun agamanya terbiasa menyelenggarakan kegiatan sosial kemasyarakatan di Jambur, makanya ketiak pindah ke Siosar, jambur adalah symbol sekaligus tempat yang tidak boleh belakangan di bangun, ia harus yang menjadi pertama sama halnya dengan rumah, karena aktivitas sosial masyarakat banyak bergantung pada Jambur tersebut. ${ }^{4}$

Respon masyarakat Sumatera Utara khususnya masyarakat Muslim terkait pengembangan masyarakat muslim Siosar beragam bentuk, ada yang focus pada penguatan akidah dan ibadah dengan menyelenggarakan pengajian dan pendidikan agama secara rutin untuk anak-anak dan orang tua, ada yang fokus pada sumbangan dalam bentuk barang untuk kebutuhan sarana dan prasarana rumah ibadah, ada dalam bentuk uang pembinaan dan sebagainya.

Pengembangan ini dimaksudkan agar masyarkaat muslim yang berada di Siosar merasa diperhatikan oleh saudaranya sesama muslim di luar kab. Karo. Pada prinsipnya seperti yang diungkapan oleh Asiah salah satu lembaga yang dimilikinya ikut serta dalam pengembangan masyarakat di sana:

"sebagai sesama muslim, saling peduli, saling membantu dan saling menyayangi adalah nilai ukhuwah, umat Islam di Siosar sangat perlu diperhatikan, mereka sedang dalam musibah, dipindahkan dari tempat asalnya ke tempat baru, sementara di sana yang beragama non Islam bantuan dari sesamanya sangat banyak dalam beragam bentuk, kita khawatir umat Islam di Siosar merasa kecil hati, oleh karena itu gerakan pengembangan masyarakat muslim dari luar cukup banyak yang memperhatikan",5

Hal ini senada dengan apa yang diungkapkan oleh Dunham bahwa pengembangan masyarakat mencakup; 1) program terencana yang difokuskan pada seluruh kebutuhan masyarakat, 2) bantuan teknis, 3) berbagai keahlian yang terintegrasi untuk membantu masyarakat, dan 4) suatu penekanan utama atas self help dan partisipasi oleh masyarakat. Lebih lanjut Dunham mengemukakan bahwa dalam usaha menggambarkan pengembangan masyarakat, terdapat 5 (lima) prinsip dasar yang amat penting yaitu (Budimanta \& Rudito, 2008): 1) Penekanan pada pentingnya kesatuan kehidupan masyarakat dan hal yang terkait dengan hal tersebut (ukhuwah). 2) Perlu adanya pendekatan antar tim dalam pengembangan

\footnotetext{
${ }^{4}$ Wawancara, Ibu Melania Sembiring, Warga Siosar beragama Kristen.

${ }^{5}$ Wawancara, Asiah, Praktisi Dakwah dan Akademisi tinggal di Kota Medan. 
masyarakat (táawun). 3) Kebutuhan akan adanya community worker yang serba bisa (multi purpose) pada wilayah perdesaan (amilun). 4) Pentingnya pemahaman akan pola budaya masyarakat lokal (márifah). 5) Adanya prinsip kemandirian yang menjadi prinsip utama dalam pengembangan masyarakat (yaqin).

Bencana sering menghasilkan solidaritas mekanistik ${ }^{6}$ yang lebih solid dalam beberapa hal pada masyarakat khususnya masyarakat yang terikat oleh ikatan kultural, ikatan keagamaan dan ikatan solidaritas kemanusiaan. Dalam konteks masyarakat Siosar menunjukkan adanya solidaritas ikatan ukhuwah Islamiyah yang berangkat dari rasa prihatin dan kepedulian akan nasib sesama meskipun tanpa mengabaikan aspek nilai kemanusiaan universal tanpa membedakan unsur kegamaan, namun dalam konteks pengembangan sering terjadi ketimpangan, oleh karena itu biasanya, ketimpangan tersebut mendapatkan respon dari ikatan emosinal berbasis tertentu dalam hal ini agama (Liliweri, 2005).

\section{KESIMPULAN}

Pengembangan masyarkat sering dilakukan karena aspek kepedulian akan situasi dan kondisi tertentu dalam masyarakat, khususnya masyarakat yang memiliki hambatan yang nyata seperti masayarkat yang mengalami bencana, berdasarkan studi kasus pada mayarakat Siosar di Kabupaten Karo, pengembangan masyarkat Islam dilakukan atas dasar dorongan solidaritas terhadap nilai ukhuwah Islamiyah. Selain itu tentu karena adanya fakto ketimpangan dalam struktur sosial yang terjadi dibandingkan dengan masyarakat yang bergama lain di lokasi yang sama. Dorongan ini menjadikan nilai solidaritas untuk terlibat dalam pengembangan dari berbagai pihak semakin kuat.

\section{DAFTAR PUSTAKA}

Abu Suhu, dkk., 2005 Islam Dakwah dan Kesejahteraan Sosial, (Yogyakarta: Fakultas Dakwah UIN Sunan Kalijaga.

Acep Aripudin. 2013. Sosiologi Dakwah. Bandung: PT. Remaja Rosdakarya

Arsip Pemerintahan Kabupaten Karo Tahun 2016.

${ }^{6}$ Menurut Emile Durhkeim mengatakan bahwa "solidaritas mekanik didasarkan pada suatu kesadaran kolektif bersama, yang menunjuk pada totalitas kepercayaan- kepercayaan dan sentimen- sentimen yang rata- rata ada pada warga yang sama itu. Ikatan dalam solidaritas ini yaitu kepercayaan bersama, cita- cita komitmen moral. Jones, Pengantar TeoriTeori Sosial. (Jakarta: Yayasan Obor Indonesia, 2009). hlm. 76. 


\section{JURNAL PEMBERDAYAAN MASYARAKAT 209 \\ Volume 9 No. 2 Tahun 2021 ISSN: 2355-8679}

Azra, Azyumardi. 2008. "Psikologi Minoritas - Mayoritas," Majalah Gatra, edisi khusus Kamis, 25 September

Badan Statistik Kabupaten Karo. 2009. Karo Dalam Angka 2009. Kabupaten Karo: BPS.

Budimanta, Arif dan Bambang Rudito. 2008. Metode dan Teknik Pengelolaan Community Development, cet. Ke II. Jakarta: CSD

Jones. 2009. Pengantar Teori- Teori Sosial. Jakarta: Yayasan Obor Indonesia

Liliweri, A. 2005. Prasangka \& Konflik: Komunikasi Lintas Budaya Masyarakat Multikultural. Yogyakarta: Pelangi Aksara

Muhammad Fu'ad dalam A. Ilyas Ismail. 2008. Paradigma Dakwah Sayyid Qutub Rekonstruksi Pemikiran Dakwah Harokah, Jakarta: Permadani.

Sihotang, Nurfin 2012., Tafsir al-Ayat ad-Dảwah ila Allah, (Padang: Rios Multicipta Padang, 2012 